"Filtration through Collodion Sacs," Edna Steinhardt.

"The Activation of Pancreatic Extract," A. R. Dochez. Eugene L. OpIE, Secretary

\section{THE AMERICAN CHEMICAL SOCIETY} NEW YORK SECTION

THE seventh regular meeting of the session of 1909-10 was held at the Chemists' Club on Friday, April 8.

Dr. F. D. Dodge read a paper entitled "Notes of the Determination of Essential Oils."

The remainder of the program consisted of a symposium on leather, arranged by Dr. Allen Rogers, which included the following papers:

"General Outline of the Industry," Allen Rogers.

"The Process of Bating," Alan A. Claflin.

"Vegetable Tanning Materials," John H. Yocum.

"Recent Advances in Chrome Tannage," Otto P. Amend.

"The Coloring of Leather," F. E. Atteaux.

"Oils used in the Leather Industry," Edgar
A. Prosser.
C. M. JoYce, Secretary

THE UTAH ACADEMY OF SCIENCES

THE third annual meeting of the academy was held at Salt Lake City, on Friday and Saturday, April 1-2, 1910.

The sessions opened at 8 P.M. Friday evening and 2 P.M. Saturday afternoon. President W. C. Ebaugh occupied the chair.

At the annual election held on Saturday afternoon, the following officers and members of the council were chosen:

President-Dr. E. D. Ball, Utah Experiment Station, Logan.

First Vice-president-C. C. Spooner, Salt Lake High School.

Second Vice-president-Dr. S. H. Goodwin, Proctor Academy, Provo.

Secretary-A. O. Garrett, Salt Lake High School.

Treasurer-John B. Forrester, Salt Lake City. Councilors-at-large-Professor Marcus E. Jones, Dr. C. T. Vorhies, A. F. Greaves-Walker.

The following papers were read at the annual meeting :

"A General Survey of the Jurassic of Southeastern Utah," John B. Forrester, Salt Lake City.

"Mendelism," Dr. E. D. Ball, Utah Experiment Station, Logan.
President's address, Dr. W. C. Ebaugh, University of Utah, Salt Lake.

"Preliminary Report on the Animals of Great Salt Lake," Dr. C. T. Vorhies, University of Utah, Salt Lake City.

"Recent Analyses of Water from Great Salt Lake," Wallace Macfarlane, Salt Lake City.

"Preliminary Report of the Plants of Great Salt Lake," L. L. Daines, University of Utah, Salt Lake City.

"Recent Progress in Economic Entomology," Professor E. G. Titus, Utah Agricultural College, Logan.

"Efflorescence or Scum on Brick Work," A. F. Greaves-Walker, Salt Lake City.

"A Reported Occurrence of Native Iron in Utah," Dr. W. C. Ebaugh, University of Utah, Salt Lake City.

"The Composition of Solids Precipitated from the Atmosphere during "Salt Storms," Dr. W. C. Ebaugh.

A. O. GarReTt, Secretary

ST. LOUIS SECTION, AMERICAN CHEMICAL SOCIETY ST. LOUIS CHEMTCAL SOCIETY

THE following papers have been presented before these two affiliated chemical societies, at the meetings held in January, February, March and April, 1910.

"Timber Preservation," Messrs. A. L. Kammerer and E. B. Fulks.

"The Action of Magnesium upon the Vapors of Organic Compounds," Professor E. H. Keiser.

"The Extraction of Glycerine from Soap Lye," Mr. Clarence B. Cluff.

"Chemistry in America and Germany," "Electrolytic Preparation of Hydrazine," Mr. R. F. Weber.

"Terpeneless Extract of Lemon, and Methods of Analysis thereof," Dr. S. H. Baer.

"A Rapid Method of Estimating Iron in Iron Ores," Dr. LeRoy McMaster.

"Ozone in Water Treatment," Mr. W. F. Montfort.

The two societies also have visited the plants of the Laclede Gas Light Company and of the N. K. Fairbanks Co., the plant of the latter company, in St. Louis, being engaged in the manufacture of laundry soap and washing powder.

R. Norris SHreve, Sec. St. Louis Sec. Amer. Chem. Soc. Geo. Lang, JR., Rec. Sec. St. Louis Chem. Soc. 